\title{
Between the unimaginable and the unthinkable: pathways to and from England's housing crisis
}

\author{
Nick Gallent, Dan Durrant and Phoebe Stirling \\ UCL Bartlett School of Planning
}

\begin{abstract}
This paper provides a critical perspective on England's housing crisis, characterised here as a concentration of wealth in residential property which is driving up prices and reducing access to the homes that people need. Housing has become a wealth machine and government has arguably lost sight of its social function. It is important that planning draws a functional distinction between housing as an asset, and housing as a social good. The paper ends by considering how a decoupling of housing's 'home' and 'asset' functions might be achieved through land-use policy.
\end{abstract}

Keywords: Housing, credit, wealth, privatisation, investment, justice, England

\section{Introduction}

England is in the grip of a housing crisis marked by rising property prices, declining affordability (relative to earnings), falling rates of home-ownership and rising levels of longterm renting, homelessness and general housing inequality (Tunstall, 2015; Edwards, 2016a). The focus of this crisis is undoubtedly on London, where demand for residential property outstrips supply and where price increases are steepest (Hilber, 2015). But England is not alone in facing these issues. Regular international market appraisals from Knight Frank (see 2016 for the most recent) highlight many examples of price inflation running far ahead of real earnings, fuelled by historically low interest rates and the global movement of capital into safe investment havens. Countries as diverse as Sweden, New Zealand, Canada and Hong Kong are singled out as popular investment destinations. The crises that such countries face (if viewed as crises rather than investment bonanzas) appear to be commonplace across late capitalist economies (Reinhart and Rogoff, 2011; Aalbers, 2016) and link to the wider economic and banking disruptions (Turner, 2008; Harvey, 2013) that precede falling interest rates and a rush of investment capital into fixed assets - commercial and residential property. The cycles of capital investment have shepherded global wealth into housing which has assumed the status of high-quality collateral, attractive to both domestic and international investors.

But these general trends are unable to account for the particularities of local situations: why some housing systems seem to weather global financial storms reasonably well whilst others descend into crisis. Focusing on England and London, this paper considers how the shifting role of state housing provision and the financialisation of housing interact with the fundamental dynamic of supply and demand to produce particular outcomes. More specifically, the apparent English turn against planning (Lord and Tewdwr-Jones, 2014), marked by growing reliance on market mechanisms and a neo-liberal approach to regulation, seems to have generated a framing of the housing crisis dominated by questions of supply: how much new housing is produced, why is it not being produced fast enough, why is regulation holding it back, how should planning be speeded-up, reformed, removed and so on. This emphasis of recent analysis seems to us to privilege a housing discourse dominated by questions of land-use planning at the expense of any broader view. This paper seeks, firstly, to develop that broader view before, secondly, looking specifically at factors determining the price of housing. By acknowledging the spatially bounded nature of a supply response, relative to the unbounded nature of the housing market and determinants of price, the systemic complexities of the housing crisis are exposed. This is the purpose of the third 
part of the paper. The housing crisis in England is not merely a matter of production outpaced by the requirement for homes. Rather, it is an investment crisis in a number of senses: investment demand (underpinned by low interest rates, limited regulation, and generous tax treatment) is a major determinant of price; and government policy supporting home-ownership has become reconciled to continual price increases, which are now viewed as critical to consumer confidence and spending.

The investment benefits of housing have been recast as a public good, but attractive returns (i.e. rising prices and rents) on housing investment are a threat to social justice if those same returns lock sections of the population out of the market for home ownership or make rents unaffordable. The final part of the paper addresses the consideration that must be given to this distinction - between the requirement for homes and the demand for investment returns associated with ownership. Planning might well be used to recognise the functional divisions within housing consumption that market evidence points towards. The use and investment value of housing could thereby be decoupled, allowing us to reclaim housing's social function.

\section{Part 1: Towards a Broader View}

\section{Pathways to Crisis}

What sort of housing crisis does England face? The word 'crisis' denotes an emergency of one type or another that can be resolved by concerted effort. Crises seem to have the characteristic of being sudden but containable. They flare up and die down. However, Gamble $(2014,29)$, in his work on the crisis of 'Western prosperity', observes that socioeconomic crises are generally the '[...] culmination of a process, summing up all that has gone before'. Far from reaching climax and resolution, they can be structural and persist beyond periodic flare-ups. As housing and economic systems have become more interconnected, the complexities of housing problems have increased. The recent referendum on the UK's membership of the European Union has brought the question of globalisation (or more specifically, the question of who wins and who loses from borderless movements of capital and people) into sharp relief as a phenomenon that generates broadly distributed impacts but sometimes narrowly concentrated benefit. Indeed, the inequities of globalisation internationally may translate into specific inequalities nationally. This seems to be particularly true in the case of housing. Open access to the housing market brings rewards for propertied interests, but the blessing felt by homeowners can be a curse to those unable to buy or rent a home in the rising tide of the market.

Herein lies what Gamble (2014) terms a 'fiscal conundrum': relatively low property and land taxes encourage the investment that drives the housing market, delivering benefit for owners. But the same taxes present a barrier against housing access to others. The broader view, in the context of globalised housing consumption, is that market-led systems appear incapable of delivering for both investment and need. Of course, the fiscal conundrum was present before globalisation: earnings have struggled to keep pace with rising house prices for many decades, especially in countries where speculative housebuilding has been prevalent and homeownership has been a majority aspiration. The current situation is different because the market pressures are broader and deeper and because public housing options have largely been eclipsed by market production and allocation (Edwards, 2016b). It is also different today because fiscal conundrums have been exacerbated by a 'governance conundrum': how our international order should manage financial flows in ways that promote wider-spread 
prosperity (Gamble, 2014). This conundrum may have played some part in shaping the result of the EU membership referendum in the UK, although it seems likely that London will remain open to the 'wall of money' (DZT, 2015; Aalbers, 2016) currently crashing into the housing market.

There have been several recent attempts to more broadly re-frame housing challenges which have not been specific to England. Aalbers (2016, cited above) seeks to relocate the financialisation of housing in a wider political economy perspective whilst Gamble (2014, also cited above) - looking at broader questions of wealth and prosperity extending well beyond housing - calls for greater understanding of the 'origins of wills and purposes' that lead systems along particular pathways. Shifts, firstly, in the desired function of housing and, secondly, in the role of the state in producing housing stand out as two important paths to crisis. The first shift sees housing transform (in policy discourse) from basic shelter, though being a gateway to social and economic opportunity (by virtue of location), to its final manifestation as an investment and savings vehicle. This investment into housing may be motivated by house price appreciation but also by relative house price stability, with housing functioning as a "store of wealth" (Fernandez et al 2016, 2446), and capital uplift or rental income an additional benefit. 'Buy-to-Live', 'Buy-to-Let' and 'Buy-to-Leave' can all now be considered "investment-oriented strategies" (Fernandez et al 2016, 2447), each with slightly different incentives, but security relative to alternative investment options being a common motivator of demand. The second shift sees the state withdraw from housing production and management, leaving a situation in which the market has to 'step in' and meet a broad mix of needs, demands and aspirations. The common denominator in both of these shifts is privatisation. The will and purpose of the market becomes more dominant over a 70 -year period after the Second World War; state intervention shrinks and it is the market function and exchange value of housing (and general profit-taking from assets; Edwards, 2016b) that comes into ascendency.

In England, the first shift was realised through incremental privatisation of the consumption of housing, particularly through the sale of public housing to sitting tenants, beginning in the 1950s and accelerating during the 1980s (Gallent and Tewdwr-Jones, 2007, Jones and Murie, 2002). The increased proportion of housing available to the market began to normalise its function as a fungible asset. The rise in private ownership during this period was also supported by an extension and liberalisation of mortgage markets (Stephens, 2007), reducing borrowing impediments and increasing available credit, which in turn began to lift prices above their 1950s base (Aalbers, 2008). Private home-ownership rose from 51 per cent of all households in 1951 to a high-point of almost 71 per cent in 2003, with the proportion of households with mortgaged property increasing alongside (DCLG, 2016a). Throughout the 1980s, there were clear policy supports for housing investment including mortgage interest relief at source (MIRAS) for all households. This was eventually abandoned (Drabble, 1990) but similar incentives - e.g. tax relief on mortgage repayments - maintained motivations for private letting, and for small-portfolio owning 'amateur' landlords to enter the market. Often highly mortgaged, these individuals have tended to be motivated by the capital gains associated with property values rather than their rental yields (Pawson and Milligan, 2013), and therefore to prioritise liquidity over tenants' security of tenure (Pawson et al, 2017). Tenancy reform in the 1980s and a continuation of tax incentives have fuelled a significant rise in buy-to-let, which accelerated dramatically in the 2000s as a rising tide of investors entered the market, using 'bricks and mortar' as a hedge against increasing uncertainty around private pensions (Edwards, 2015). 
The second shift, a mirror to the first, was the ending of public housing production. Since the beginning of the 1980s, the amount of social housing (from public and third sector providers) in England has fallen from nearly $32 \%$ to just over 17\%. Rates of public sector housebuilding are now miniscule. But the loss of public housing (and near-cessation of new public provision) has not followed a simple narrative. The public provision of the 1970s, through which housing for subsidised rent was supplied in significant quantities through direct build, contrasted sharply with the transformation of provision from the late 1980s onwards, when social housing became a more complex product. Local authorities took on an enabling role, working with housing associations and the private sector to procure an increasingly marketised form of social housing - occupied on a shared-ownership basis and eventually let at market-linked ('affordable') rents. The planning system became a key mechanism for funding this housing, with landowners and developers required to contribute on-site affordable housing as part of a negotiated planning gain (Crook et al, 2016). This meant that the supply of social housing became dependent on private sector output; and the decline in public subsidy placed upward pressure on rents as production costs needed to be recovered elsewhere.

When rising costs jeopardised the affordability of social housing, subsidy was switched from bricks and mortar to individual households judged to be facing priority need (Hills et al, 1990). Public and social housing was replaced with a system of 'Housing Benefit' that would meet social or market rents, increasingly redirected to private landlords. In this way, government became locked into the private rental market, with benefit payments spiralling upwards alongside private rents (in the last 5 years, local authorities in Britain have spent f3.5 billion on temporary accommodation for homeless households, BBC, 2016). This form of personal subsidy had been viewed, in the 1980s, as a short to medium term cost of withdrawing from direct provision - payable to workless or low-income recipients. But with housebuilders focused on delivering for home-ownership, the expansion of the private rental sector occurred largely through amateur landlordism. With this sector now largely owned by individuals rather than businesses or institutions (Pawson et al, 2017), landlords' investments (and mortgage repayments) were not able to keep pace with growing demand for genuinely affordable tenancies. Subsequent inflation of rents means that a growing number of working households now rely on Housing Benefit (Holmans, 2014). Dorling (2014) has argued that by subsidising individuals rather than building homes, government has propagated a negative circularity, with former social housing tenants now reliant on a largely unregulated and often unaffordable private rental sector, sometimes paying their housing benefit to buy-to-let investors. This narrative, therefore, sees the money that was once spent on building homes redirected to private housing investment, widening the divide between rentier and propertied housing classes.

\section{Calculable demand and constrained supply}

The two pathways point to a commodification of housing manifest in new patterns of investment (by those with greater income and wealth) and new depths of inequality (experienced by the vulnerable or by those with more limited means). The point to carry forward is that housing has been imbued with a function that extends beyond shelter: the expectation of positive investment return, above that attainable from other assets, has expanded the market for housing. State subsidies that once went into public housebuilding today reinforce the marketization of housing and inflate investment returns. Yet despite this significant shift in the broader system, the demand for housing is still considered calculable and tied to the 'use value' (rather than exchange or investment value) that new households attach to bricks and mortar. Demand is considered knowable and linked always to utility. 
Thereafter, the solution to the declining affordability, falling rates of home-ownership, homelessness and general inequality flagged at the beginning of this paper must lie in the building of more homes. And increased supply relative to measured demand is achievable through reduced regulation and more relaxed land-use planning. The difficulty we have with these perspectives is that demand is neither tied to utility nor spatially bounded and that additional supply is, on its own, an inadequate response to unbounded demand.

The stranglehold that these perspectives have on housing debate in England perhaps requires some elaboration. Projections of household formation are generally thought to accurately reveal the level of future housing demand across the country. Formation rates are regularly presented alongside other data (e.g. housing starts and completions) to reveal demand / supply mismatches that are then used to explain rising house prices and inadequate access. For example, the Lyons Review of Housing Supply has claimed that ' $[. .$.$] we need to build at least$ 243,000 homes a year to keep up with the number of new households being formed, but last year we only built 109,000 homes [and] without a change of course, it is predicted that the country will be short of up to two million homes by 2020' (Lyons Review, 2014, 6). The opening figure has unacknowledged limitations: it is a guess at the extent of newly-arising utility-based demand that will be activated by forming households with the capacity to pay market prices and rents. The figure fails to capture investment demand, inferring instead that demand is bounded (in space) and responsive only to the need to be housed. Both inferences are flawed.

An appreciation of the origins of household projections helps explain their continuing value and their increasing limitations. After the Second World War, a methodology was developed for translating population figures - previously used to keep track of future public pension eligibility - into household projections (Gallent, 2005). These became a key planning tool at a time when local authorities and New Town Development Corporations were advancing significant public housing programmes: they provided a measure of the future requirement for a largely non-marketised product being delivered as part of more comprehensive state welfare (Gallent, 2016). The privatisation of housing production and consumption described above - alongside the refunctioning of housing as investment, and emergent and unbounded patterns of demand - has strained the connection between projections and requirement. Because they track the mix of households forming and the age-profile of the population, projections provide an important tool for estimating future health care needs, school place demand and pension costs. But these, in large part, remain public goods. The challenge in relation to housing is that need does not link neatly to household formation. A proportion of demand is expressed by non-residents: domestic second home buyers in some locations, international investors in others. Projections provide a 'starting point' for estimating housing requirements but only if 'market evidence is given proper weight' (Whitehead, 2016, 417).

Projections provided key intelligence for public housing programmes, but are less useful today for predicting patterns of market demand and consumption. However, they have maintained centre-stage in public and political discourse. The headline projection figure (noted in the Lyons Review) is taken to be the amount of housing that the country should be building. But whilst it underscores the need to deliver new housing in some areas, it does not reveal the scale of building required to progress an effective supply response in the absence of any demand-side intervention. In order to meet demand without seeking to manage that demand or divert investment pressure to other assets, building rates will need to significantly exceed household formation for a sustained and extended period (HBF, 2014) requiring 'output levels of well over 400,000 per annum over many years' (Whitehead, 2016, 419). 
Such is the route out of the current housing crisis plotted by supply-side 'fetishists': but as Williams (2016, no page) has claimed this crisis '[...] will not be solved by the supply-side fetish, in which incentivised developers and overhauled planning laws create enough housing for all. Rents are increasing because power is concentrated in the hands of property owners; house prices are booming because the investment potential is irresistible to the holders of capital'. That the crisis is underpinned by capital movements (into housing) and imbalances in market power has been a difficult pill for successive governments to swallow. It has been easier to incentivise housebuilding whilst viewing the crisis as a market held back by overzealous bureaucracy. Government has projected an image of ordinary 'working families' pitted against embedded regulation, which is synthetic and impedes the proper functioning of markets. Capital movements and market power are part of a much broader economic system into which housing has been sucked and cannot, without fundamental change, be extricated from. This has made government highly receptive to anti-regulation sentiment and calls to speed-up the planning process (see Barker, 2006). Planning reforms since 2010 have been billed as simplifications aimed at facilitating housing growth (Clarke, 2012). They have been built on critiques of the planning system laying blame for rising prices at its door (Nathan and Overman, 2011).

Recent criticisms of land-use planning are rooted in a longer history of analysis (especially Peter Hall and colleagues' Containment of Urban England, 1973) which has presented the need for housing growth in a context of social, political and planning impediments. For Hall et al (1973) post-war planning and containment was a victory for rural shires - with their green fields and their NIMBY's - and a defeat for overcrowded towns and cities, henceforth to be enveloped by Green Belts. Similar views were aired in Alan Evan's 1991 analysis of housing standards and affordability: restrictive planning was supported by several 'myths' about England's development capacity and the priority given to environmental protection. Inevitably, planning constraint can impede housing supply and result in access barriers. Given that planning decisions are rooted in local politics (generating what Barker, 2004, termed an 'implementation gap' in housing delivery) as well as land-use and national priorities, it seems inevitable that the rate of housebuilding can be impacted upon, locally and in aggregate. Indeed, suggestions that the housing crisis is mainly about planning (e.g. Cheshire, 2009; Hilber and Vermeulen, 2010; Hilber, 2015) have found a ready audience in policy circles, largely because they align with government's preference for deregulation. Such deregulation, however, is a double-edged sword, generating a level of (global) demand for housing through its support for financialisation that cannot be met through (local) supply even in the context of much looser planning. Cheshire et al (2014) agree that household projections offer a partial view of housing requirement; but whilst they see rising house prices (and increasing housing space consumption) as being determined by income rises (more housing needs to be built to keep pace with aspiration), it is the movement of wealth (overseas and domestic capital) into housing that seems to be having a more disruptive effect today than when either Hall and colleagues, or Evans, were commenting on planning constraint (Rossall Valentine, 2015).

\section{Part 2: Price Determination}

The UK's housing system is 'mixed' in a number of senses. The recognition of private housing as a merit good - with access dependent on market position - necessitates a mix including 'administrative provision' (Whitehead, 1991) to guarantee wider access. The system is also mixed in the sense that use and exchange value underpin the logic of home ownership (Barker, 2014). But recent years have seen a dramatic rebalancing of these two 
values. Use value, being linked to requirement for space and location, can be thought of as relatively stable (or set within fixed limits, extending some way beyond utility towards luxury). It is exchange value, therefore, that appears unlimited with housing often now insured for many times its rebuild value. The movement of prices well beyond use value marked a point at which housing assumed a broader economic function, with housing wealth-effects linking prices with consumer confidence and spending (Aoki et al, 2001). This has prompted a redirection of the housing system in support of economic performance. The boost to performance that is prompted by consumption - and driven by consumers' desire to grow the exchange value of their assets - has informed a preference for price-responsive housing provision (rather than a demography-driven approach). But as prices rise, demand is choked off within conditions of limited supply. The result is problematic for three groups: for households who actually need housing, where investment potential may be an important but secondary consideration; for investors who do not yet hold any housing assets, locked out of the benefits of equity growth; and for everyone else reliant on the economic boost that access to homeownership generates. The privileging of supply over investment regulation in addressing these problems evidences government preoccupation with housing as an economic rather than social good.

Price shifts are, largely, driven by the trading of property within the existing housing stock (often by landlords and other investors). New build - even when national targets are achieved - represents on average no more than 1\% of that built stock (Bramley and Watkins, 2015), meaning the relationship between housebuilding and price change at neighbourhood level can be minimal and short-term (Whitehead et al, 2015). But efforts to model the link between prices and housing stock increases reveal 'significant' price effects (Bramley and Leishman, 2005). Muellbauer and Murphy $(2008,10)$ have predicted falls of between 1.5 and $2 \%$ in regions where there is a $1 \%$ rise in housing stock relative to working-age population. This link with resident population suggests that robust models are possible where the market for housing is localised, but less predictable where sources of market demand are varied. But the $1 \%$ increase in supply is also important. This equates with roughly 300,000 new homes in England, and is suggestive of the amount of housebuilding required to flatten the market before refocusing on the greater complexities of investment-driven demand. If supply is seen as the sole determinant of, and only response to, price rises then a massive housebuilding programme must be embarked upon.

This was the realisation of the Barker Review (2004), subsequent work by the National Housing and Planning Advice Unit (NPHAU, 2007) and analysis by academic commentators (Meen, 2011). Over-supply relative to standard measures of demand (taking their cue from demography) is essential if a good proportion of basic need is to be met. However, the inelasticity of supply in response to demand may have some positive effects, as witnessed in the aftermath of the 2008 crisis. Unlike some of its European neighbours - notably the Republic of Ireland and Spain - the UK did not experience a boom in new housebuilding as easy credit, low interest rates and soaring demand pushed up real estate prices. Overproduction on a massive scale, and often in peculiar locations, triggered bankruptcies that deepened the crisis for Irish and Spanish banks (Duca et al, 2010; Dolphin and Griffin, 2011). Quickly turning on the supply tap in response to prices poses significant risk, as those prices are not only determined by 'trends' in the supply / demand dynamic (which are independent from the economic cycle) but also by a number of cyclical drivers (which are tied to it). Meen (2012) contrasts the more predictable factors affecting real house prices (including those viewed as stable and knowable, such as fiscal treatment of housing and planning regulation) with those which are more volatile and linked to economic cycles and, increasingly, the global inter-connectedness of economies. Hence, income (including 
earnings), interest rates, credit availability (and lender assessments of risk), wealth accumulation and movement (across borders), expected capital gains from one asset compared to another, changing labour and construction costs, and rates of economic activity all impact on prices (see Table 1).

\begin{tabular}{|l|l|}
\hline Cycle & Trend \\
\hline Income & Population size and structure \\
Interest rates (real and nominal) & Headship rates \\
Credit availability & Migration \\
Wealth & Housing stock and planning regulation \\
Expected capital gains & Housing taxation \\
Construction costs & \\
Employment/ unemployment & \\
\hline
\end{tabular}

Table 1: Factors affecting real house prices (Meen, 2012, 357)

The role of wealth (and cash-buying), credit (and underlying money creation by deregulated banks) and producer behaviour (counter-balancing the impact of land-use constraint) in determining house prices and affecting access, have all been recently reconsidered. Rossall Valentine's (2015) examination of foreign investment in the UK housing market shines a light on the movement of footloose global capital into the country and especially into 'prime' London property. The extent of this overseas demand in the London prime and super-prime housing market is well documented (Atkinson et al, 2017; Civitas, 2014; Sassen, 2014). Atkinson et al (2016a) provide a detailed account of the geography of hyper-consumption in London's housing market, identifying 'alpha' areas with significant concentrations of highnet-worth buyers. London seems to be more indiscriminately attractive to foreign investment than other locations, with capital flowing into the city from across the globe (Sassen, 2014, 134), but the highest percentage of foreign buyers come from Russia, France and more recently from China, with Chinese investors accounting for $11 \%$ of house purchases above $f 1 \mathrm{~m}$ in 2014 (Rossall Valentine, 2015, 22). One of the conclusions from these studies is that investment buying now extends out of the most desirable post-codes, with many outer-London boroughs drawing interest from overseas buyers. Attractive returns on capital invested in London housing have been maintained following the 2008 credit crisis (Gallent, 2016; Gallent et al, 2017). Limited tax liabilities (including outdated council tax valuations and one-off stamp duty, avoidable when purchased through off-shore holdings) combined with unrelenting price rises and soaring rents mean that UK housing is hugely popular with non-domiciled investors, with over $f, 5$ billion overseas investment in the London property market in 2011 alone (Atkinson et al, 2016b, 1). The scale of demand for prime properties in London has displaced the demand for less expensive investment opportunities, and produced new patterns of ownership across the country - particularly in buy-to-let, second home and holiday home ownership (Gallent et al, 2016), with Buy-to-Let mortgages now accounting for 18\% of new housing loans nationally (Rossall Valentine, 2015, 25).

The new Mayor of London, Sadiq Kahn, has launched an inquiry into foreign investment in London housing (Taylor and Phillips, 2016) but has been careful to underscore the benefits of external investment in new housebuilding. The delivery of new 'affordable housing', as noted above, is dependent on getting speculative projects off the ground and it is overseas money that often underpins such schemes in London. It is also the case that the aspiration to deposit wealth in housing is not confined to foreign buyers, who are simply exploiting the opportunities designed into the system. Domestic policy has long nurtured this aspiration and the movement of overseas wealth into housing may now be considered one further 
source of reassurance for UK home-buyers whose borrowing plans are shaped by expectations of rising prices.

New buyers - lacking a store of accumulated wealth - are often dependent on credit for entry into the market, which then becomes a determinate of price: the more credit available, the higher prices will go, assuming supply is finite. Supply of credit is, in turn, dependent on banking and lending arrangements. Wainwright (2009) identifies bank deregulation, and changes to rules linking loans to deposits, as crucial to both credit availability and the credit crisis. When money lent no longer needs to be balanced by deposits held, then a process of private 'money creation' (McLeay et al, 2014) is allowed to accelerate and the supply of money outpaces that of available property (Ryan-Collins et al, 2012). Less attention is given to the asset on which the loan is to be secured and the financial credentials of the borrower. In the worst case scenario, assets are over-valued and credit is advanced to those who may struggle to repay. Once such practice becomes systemic, personal struggles become structural and even global through the securitization of high-risk residential loans. Indeed, securitization - the selling on of contractual debt to third-party investors - is now the principal means by which housing is commoditised and then financialised, making national economies reliant on house-price growth.

Development booms - of the type witnessed in Spain and the Republic of Ireland - happen when national governments and housing producers decide that rapidly increasing supply is the best means of capitalising on credit-based growth. The ensuing collapse in prices is one form of crisis, with deep economic repercussions. Another form arises when the supply of money - an outcome of credit availability - pushes up against a finite supply of housing. Planning constraint then undoubtedly magnifies the price-setting effect of credit, alongside the behaviour of speculative housebuilders. Payne (2013) shows that it is in the interest of housing producers to trickle new supply onto a local market: controlled supply, relative to gauged demand, is key to a more sustainable business model. Housebuilders take a longterm view, will seek to control the land-market (and the phased release of land for development; see Salway, 2014), and develop at a rate judged to maximise capital return. Seen in the context of apparent demand for housing and projections of household formation, this is another reason that the private production of homes lags behind government targets.

\section{Part 3: An Unbounded Investment Crisis?}

This brief examination of price determination reveals that in a privatised and financialised housing system there is no simple link between the need for housing and levels of demand as expressed by price. Investment and financialisation obscure any clear view of the need for housing unless our definition of need recasts housing as collateral for borrowing and privileges its economic function. The current situation in England is not unique: the movement of wealth into housing, its central role in money creation, the privatisation of housing production and consumption are common to numerous countries. But housing policy debate in England is relentlessly focused on local peculiarities: the distinctiveness of UK planning systems and speculative rather than contract production by market actors. Depending on one's political leaning, either planning is too restrictive (restraining development) or speculators too greedy (drip-feeding the market); their common outcome being that not enough housing is built. The crisis is boiled down to one of supply.

If this is the case it must necessarily be seen as a failure to meet not only the need for housing but also the need for investment in support of house prices, consumer confidence and economic growth, activated as demand in the market. To meet all need, there must be a 
step-change in the achieved level of housing supply. National output sustained at above 400,000 units per year should slow the rate of inflation and eventually stabilise real house prices (Whitehead, 2016). This may, in itself, remove those investors looking for higher returns from the market. But others may enter, seeking to benefit from new opportunities arising from increased supply. Simply building more homes (predicated on further incentives to market actors, encouraging them to break away from current patterns of behaviour) presents many risks, not only in terms of place and environmental quality, but also in terms of market response and potential failure.

The housing crisis appears intractable because the level of new building needed to respond to market pressures is unprecedented and, for many, unimaginable. Most of the new homes will need to be built in and around London, many on the Metropolitan Green Belt (Mace et al, 2016). And if a step-change in building rates is unimaginable, so too is any fall in house prices. Hundreds of thousands of recent home-buyers have spent decades chasing rising prices, being eventually helped onto the housing ladder by a combination of historically low interest rates, family support, huge mortgages and periodic government assistance. They now find themselves at the top of a pyramid scheme (Mei, 2016) with continuing price inflation dependent on government's commitment to home-ownership to enlarging the flow of investment into housing.

Reduced movement of wealth into housing (including from international sources) could calm the housing market, but with private housing debt, relative to income, now much higher in the UK than in other developed economies, any stagnation of prices would hit consumer confidence and spending. England is hooked on the housing drug; the question now seems to be whether reduced investment and falling prices would increase housing access, or whether economic growth, fuelled by new waves of investment and driving 'good inflation' in house prices (Hay, 2009) - possibly from an enlarging Chinese middle class (Barton et al, 2013) - would bring broader economic benefits that will, at last, 'trickle down'.

But the unbroken trajectory over the last 30 years has been towards greater housing inequality, measured in terms of access to space (Tunstall, 2015). The recent surge in international investment (Atkinson et al, 2016a, b) has done nothing to reverse that trend. Investment in the form of production finance for speculative residential schemes may also deliver 'affordable housing' through planning gain, but the amount and the actual affordability of that housing is inadequate, given the widening gap between housing costs and incomes. There is of course the possibility of gradually slowing the movement of wealth into housing through incremental changes to taxation - for example, by introducing capital gains liability on the onward sale of primary residences, payable on 'final transaction' from the estate of deceased owners, or by reform of council tax (Barker, 2014) - or through reform of bank regulation and lending rules, reconnecting loans to deposits held. But such moves represent a significant reversal of decades-old support for homeownership, and recent history suggests that those with the greatest housing need are unlikely to benefit from the recession likely to accompany a fall in house prices. And even if recession could be avoided, gradual deflation of the housing bubble would not bring fast relief for households still currently locked out of the market

\section{Conclusions: between the unimaginable and the unthinkable}

The housing system has been long in the making. It cannot be unmade by any single action. In order to deliver short-term relief, a range of interventions designed to compensate for current inequities will need to continue: more grant-supported public or third sector 
provision; more affordable housing that is genuinely affordable, some delivered with planning gain; more development on public land and the former military sites, and greater revenue collection on properties left empty for extended periods (Atkinson et al, 2016b, 7), generating revenues that can be reinvested in affordable housing, preferably with 'social' rather than 'affordable' rents. But such interventions do not add up to the required re-tasking of the housing system - re-tasked to provide homes before investment opportunities. The same is true for increased supply in the context of a retained investment market. Like gradual adjustments to tax liability, turning on the supply tap - and achieving the 'unimaginable' level of housebuilding suggested above - is likely to bring slow and localised change to house prices. Like the oil-tanker, the direction of the housing system, and its outputs, can be changed only very slowly. But unlike the oil-tanker, there are many interests - in government, finance, and society at large - who will oppose any change of direction. Indeed, there is a natural preference for short-term interventions over long-term change. The housing system seems to work for many and reaching those in greatest need is not always a priority for the well-housed majority.

But the current system is sustaining a crisis that is engulfing an ever-greater proportion of households in England. That crisis is predicated on the concentration of housing wealth achieved through the privileging of homeownership and rewards for landlordism. Tunstall (2015) has recently charted England's return to 'Victorian levels' of housing inequality. Available data suggest that inequality will grow in the decades ahead. One key objective of any housing system, in our view, should be to deliver a degree of housing justice - access that is fair and evenly distributed, giving people the opportunity to live where they need to, in homes that are well-suited to their needs. Smashing the current system is not an answer to the current crisis, but nor is ignoring the injustices it produces. Given the interconnectedness of global capital, the English housing system might be seen as a bit player in a wider drama, impotent in the face of supra-national frameworks and flows that generate local outcomes. But other countries, China included, are now taking actions on 'overinvestment' in the housing market; actions limiting the consumption of housing that evidence concerns around price-inflation, the creation of investment bubbles and systemic risk to capital and growth (Ren, 2016). Of course, China's economy is far less reliant on housing wealth in support of consumer spending than that of the UK. Strict limits on property purchasing may not suit the UK's economy. There is broader economic need to retain interest in housing investment and this might be achieved by combining more incremental actions on tax and investment with a re-tasking of the planning system.

A number of commentators have laid the blame for the housing crisis at planning's door (Cheshire, 2009; Hilber, 2015) and we agree that the system could play a bigger part in ensuring that England has the housing it needs. We do not think that this will happen through neoliberal actions: deregulation or the relaxing of land-use rules or through a disempowering of local authorities in favour of permitted development. Rather, it will be achieved by tasking authorities to allocate land for housing that is needed before allocating for openly tradeable property of the type desired by investors. A new 'housing delivery test', outlined in the 2017 White Paper (DCLG, 2017, 43), is aimed at understanding why houses built might lag below target in certain areas. These targets will, for the moment, continue to be based on published household projections where plans are lacking, but from April 2018 a new 'standardised approach to assessing housing requirement' will be introduced. Reversion to the presumption in favour of sustainable development where requirements are not fulfilled suggests that these targets will continue to be used as a means to privilege increasing supply. But approaching a new understanding of housing requirement should instead mark an opportunity to interrogate the nature of demand beyond simple 
demographics - and a role for planning beyond indiscriminate land release for increased and speedier development.

One possibility would be for government to redefine and therefore refunction housing; to distinguish, in planning law, between 'resident' and 'investment' housing. Under such a system, no household would be permitted to purchase more than one 'resident' home and all such homes would be subject to capital gains tax on onward sale. The value of land allocated for resident housing would be depressed, but not to the same extent as land restricted to building for target groups. Resident housing would be accessible to all households needing to live and work anywhere in the country who did not own another home of this type: all newly forming households or those seeking to move from the rental sector. There is no reason to imagine that selling land for resident housing, or building such homes, would not be an attractive proposition for private enterprise, but tax and ownership rules would limit the accumulation and concentration of wealth in such housing. Given the current needs of the economy, that displaced wealth might look for a new home, which would be provided by investment housing permitted and built on surplus land, not needed for resident housing. Investment housing in the new-build segment of the market would assume greater scarcity value, being tradeable across a global market.

Whilst it might also be possible to vary housing classes to a greater extent, creating new opportunities for professional investment in rental housing, the point here is that planning might be engaged to limit the concentration of wealth in housing, which is central to the housing crisis. Depending on tax rules, some potential for equity growth could be maintained, providing households with the means to cover transaction costs once they need to move home. Similarly, expectations from ownership would change, opening the door to a great many housing models - including mutual and pooled ownership - that have struggled to get a foothold in the current open-market system. One of the dangers of this planning remedy is that engrained expectations of ownership would drive investment to the secondhand market, pushing up prices there and depressing demand for new housing and therefore its supply. That is why any reformed approach to new-build must be coupled with incremental capital gains and council tax changes applied to existing housing.

It is easy to reject such unorthodox ideas. Powerful interests are railed against them because they cannot be reconciled with established property rights or the expectation that housing should perform as any other asset, delivering equity growth that, for some owners, exceeds earnings. Housing has become part of a 'wealth machine' (Edwards, 2002) but it is now clear that that machine is failing to deliver housing justice for an increasing proportion of England's population. The choice before us, in the face of an existential housing crisis, is between an unimaginable level of housebuilding - in response to unbounded market demands - and an unthinkable refunctioning of housing. It seems likelier that the crisis will rumble on.

\section{Acknowledgements}

This work in which this paper is based was supported by UCL Grand Challenges. We are particularly grateful for the guidance and encouragement provided by Ian Scott and James Paskins.

\section{References}

AALBERS, M. (2008), 'The Financialisation of Home and the Mortgage Market Crisis', Competition \& Change, 12, 137-149 
AALBERS, M. (2016), The Financialisation of Housing: A Political Economy Approach, London, Routledge AOKI, B. K., PROUDMAN, J., and VLIEGHE, G. (2001), Why House Prices Matter, London, Bank of England

ATKINSON, R., BURROWS, R. and RHODES, D. (2016a), 'Capital City? London's Housing Markets and the 'Super-Rich", in I. Hay, and J.V. Beaverstock, (eds.), Handbook on Wealth and the Super-Rich, London, Edward Elgar, 225-243

ATKINSON, R., BURROWS, R., GLUCKSBERG, L., HO, H-K., KNOWLES, C., RHODES, D. and WEBBER, R. (2016b), International Capital Flows into London Property, SPERI Global Political Economy Brief No.2, Sheffield, SPERI

ATKINSON, R., PARKER, S. and BURROWS, R. (2017), 'Elite Formation, Power and Space in Contemporary London', Theory, Culture \& Society, 34,179-200

BANK OF ENGLAND (2015), Financial Stability Report - Part A: UK Housing Market, Issue No. 37 (Accessed 10 November 2016 at http://www.bankofengland.co.uk/publications/Documents /fsr/2015/fsr37sec4.pdf)

BARKER, K. (2004), Review of Housing Supply, London, HM Treasury

BARKER, K. (2014), Housing: Where's the Plan? London, The London Publishing Partnership

BARTON, D., CHEN, Y. and JIN, A. (2013), 'Mapping China's Middle Class', McKinsey Quarterly, June 2013

BBC (2016), 'Councils spent $f^{3} 3.5$ billion on temporary housing in last 5 years', 17 November 2016, at http://www.bbc.co.uk/news/uk-38016728

BRAMLEY, G. and LEISHMAN, C. (2005), 'A Local Housing Market Model with Spatial Interaction and Land-use Planning Controls', Environment and Planning A, 37, 1637-1649

BRAMLEY, G. and WATKINS, D. (2015), 'Housebuilding, demographic change and affordability as outcomes of local planning decisions: Exploring interactions using a sub-regional model of housing markets in England', Progress in Planning, 104, 1-35

CIVITAS (2014), Finding Shelter: Overseas Investment in the UK Housing Market (Accessed 21 September 2017 at http://www.civitas.org.uk/publications/finding-shelter/)

CHESHIRE, P. (2009), Urban Containment, Housing Affordability and Price Stability - Irreconcilable Goals, Spatial Economics Research Centre (SERC), London, LSE

CHESHIRE, P. (2014), Turning houses into gold: the failure of British planning. (http://blogs.lse.ac.uk/politicsandpolicy/turning-houses-into-gold-the-failure-of-britishplanning)

CHESHIRE, P., NATHAN, M. and OVERMAN, H, G. (2014), Urban Economics and Urban Policy: Challenging Conventional Policy Wisdom, London, Edward Elgar

CLARKE, G (2012), DCLG Press Release (Accessed 12 September 2016 at https://www.gov.uk Lgovernment/news/planning-reforms-will-deliver-local-growth-with-community-support--2)

CROOK, T., WHITEHEAD, C. and HENNEBERRY, J. (2006), Planning Gain: Providing Infrastructure and Affordable Housing, London, Wiley

DCLG (2016a), Live Tables - Table FT1101 (S101) (Trends in Tenure), (Accessed 10 November 2016 at https://www.gov.uk/government/uploads/system/uploads/attachment data/file/538745/ FT1101_Trends_in_tenure.xlsx)

DCLG (2016b), Live Table 212, (Accessed 10 November 2016 at https://www.gov.uk/government Luploads/system/uploads/attachment data/file/547834/LiveTable212.xlsx)

DOLPHIN, T. and GRIFFITH, M. (2011), Forever blowing bubbles? Housing's Role in the UK Economy, London, IPPR

DORLING, D. (2014), All that is Solid: The Great Housing Disaster, Harmondsworth, Penguin

DRABBLE, M. (1990), Safe as Houses: Examination of Home Ownership and Mortgage Tax Relief, London, Chatto \& Windus

DUCA, J. V., MUELLBAUER, J. and MURPHY, A. (2010), 'Housing markets and the financial crisis of 2007-2009: Lessons for the future', Journal of Financial Stability, 6, 203-217

DZT (2015), 'Available capital reaches new peak record level', DZT Insight, 20, April 2016.

EDWARDS, M. (2002), 'Wealth creation and poverty creation', City, 6, 25-42

EDWARDS, M. (2015), Prospect for Land, Rent and Housing in UK Cities, London, Government Office for Science

EDWARDS, M. (2016), 'The housing crisis and London', City, 20, 222-237 
EDWARDS, M. (2016b), 'The housing crisis: too difficult or a great opportunity', Soundings, 62, 2342

FERNANDEZ, R., HOFMAN, A. and AALBERS, M. (2016), 'London and New York as a safe deposit box for the transnational wealth elite', Environment \& Planning A, 48, 2443-2461

GAMBLE, A. (2014), 'Crisis without End? The Unravelling of Western Prosperity', London, Palgrave

GALLENT, N. (2005), 'Regional Housing Figures in England: Policy, Politics and Ownership', Housing Studies, 20, 973-988

GALLENT, N. (2016), 'Investment, global capital and other drivers of England's housing crisis', Journal of Urban Regeneration and Renewal, 9, 122-138

GALLENT, N., DURRANT, D. and MAY, N. (2017), 'Housing supply, investment demand and money creation: a comment on the drivers of London's housing crisis', Urban Studies, 54, 22042216

GALLENT, N., KELSEY, J. and HAMIDUDDIN, I. (2016), 'Swimming Against a Cornish Tide', Town \& Country Planning, 85, 237-240

GALLENT, N. and TEWDWR-JONES, M. (2007), Decent Homes for All? London, Routledge

HAY, C. (2009), 'Good inflation, bad inflation: The housing boom, economic growth and the disaggregation of inflationary preferences in the UK and Ireland', The British Journal of Politics \& International Relations, 11, 461-478

HALL, P., THOMAS, R., GRACEY, H. and DREWETT, R. (1973), The Containment of Urban England, Allen \& Unwin, London

HARLOE, M. (1995) The People's Home? Social Rented Housing in Europe and Australia, Oxford, Blackwell HARVEY, D. (2013), Rebel Cities: From the Right to the City to the Urban Revolution, New York, Verso

HILBER, C. and VERMEULEN, W. (2010) The Impacts of Restricting Housing Supply on House Prices and Affordability - Final Report, London, DCLG

Hilber, C. (2015), UK Housing and Planning Policies: The Evidence from Economic Research, London, LSE

HILLS, J., HUBERT, F., TOMANN, H. and WHITEHEAD, C. (1990), 'Shifting subsidy from bricks and mortar to people: experiences in Britain and West Germany', Housing Studies, 5, 147 167

HOLMANS, A. E. (2014), Housing need and effective demand in England a look at "the big picture", Cambridge, Cambridge Centre for Housing and Planning Research

HOME BUILDERS FEDERATION (2014), Barker Review: A Decade On, London, HBF

JONES, C. and MURIE, A. (2002), Right to Buy: Analysis and Evaluation of a Housing Policy, London, Blackwell Publishers

KNIGHT FRANK (2016), Residential Research: Global House Price Index, Q2 2016, London, Frank Knight

LORD, A. and TEWDWR-JONES, M. (2014), 'Is planning 'under attack'? Chronicling the deregulation of urban and environmental planning in England', European Planning Studies, 22, 345361

LYONS HOUSING REVIEW (2014), Mobilising across the nation to build the homes our children need, (Accessed 10 November 2016 at http://www.yourbritain.org.uk/uploads/editor/files/ The Lyons Housing Review 2.pdf)

MACE, A., BLANC, F., GORDON, I. and SCANLON, K. (2016), A 21st Century Metropolitan Greenbelt, London, London School of Economics

MCLEAY, M., RADIA, A. and THOMAS, R. (2014), 'Money creation in the modern economy', Quarterly Bulletin, Q1, London, The Bank of England

MEEK, J. (2014), 'Where will we live?' London Revien of Books, 36, January 2014

MEEN, G. (2011), ‘A Long-Run Model of Housing Affordability', Housing Studies, 26, 1081-1103

MEEN, G. (2012), 'House Price Determination', in S.J. Smith, (Editor-in-Chief) International Encyclopaedia of Housing and Home (Vol. 3), Amsterdam, Elsevier

MEI, T. (2016), 'The housing market is looking worryingly like a pyramid sales scam', The Conversation (Accessed 10 November 2016 at http://theconversation.com/the-housing-market-is-lookingworryingly-like-a-pyramid-sales-scam-65277)

MINISTRY OF DEFENCE (2016), A Better Defence Estate, London, MOD

MUELlBAUER, J. and MURPHY, A. (2008), 'Housing Markets and the Economy: The Assessment', Oxford Review of Economic Policy, 24, 1-33 
MUELLBAUER, J. (2012), 'Housing and the macro economy', in S.J. Smith (Editor-in-Chief) International Encyclopaedia of Housing and Home (Vol. 3), Amsterdam, Elsevier

NATHAN, M. and OVERMAN, H.G. (2011) What We Know (and Don't Know) About the Links between Planning and Economic Performance, SERC Policy Paper 10, London, SERC

NIEMIETZ, K. (2016), Liberating the housing market through fiscal decentralisation, (Accessed 4 April 2016 at http:/ /www.iea.org.uk/blog/liberating-the-housing-market-through-fiscal-decentralisation)

NATIONAL PLANNING AND HOUSING ADVICE UNIT (2007), Meeting the Housing Needs of an Aspiring and Growing Nation, London, DCLG

PAYNE, S. (2013), 'Pioneers, pragmatists and sceptics: speculative housebuilders and brownfield development in the early twenty-first century', Town Planning Review, 84, 37-62

PAWSON, H., HULSE, K. and MORRIS, A. (2017), 'Interpreting the Rise of Long-Term Private Renting in a Liberal Welfare Regime Context', Housing Studies, 32, 1062-1084

PAWSON, H. and MLLLIGAN, V. (2013), 'New dawn or chimera? Can institutional financing transform rental housing?' International Journal of Housing Policy, 13, 335-357

REINHART, K. and ROGOFF, C. (2011), This Time is Different: Eight Centuries of Financial Folly, Princeton, Princeton University Press

REN, D. (2016), 'Shanghai tightens rules on buying second homes to cap soaring property prices', South China Morning Post, 26 March 2016

ROLNIK, R. (2013), 'Late Neoliberalism: The Financialization of Homeownership and Housing Rights', International Journal of Urban and Regional Research, 37, 1058-1066

ROSSALL VALENTINE, D. (2015), Solving the UK Housing Crisis, London, The Bow Group

RYAN-COLLINS, J., GREENHAM, T., WERNER, R. and JACKSON, A. (2012), Where does money come from? (Accessed 22 June 2016 at http://www.neweconomics.org/publications/entry/wheredoes-money-come-from)

SALWAY, F. (2014), 'A Developer's Perspective', in A. Adonis, B. Rogers and S. Sims (eds.) Go East: Unlocking the Potential of the Thames Estuary, London, Centre for London: London, 72-79

SASSEN, S. (2014), Expulsions: Brutality and Complexity in the Global Economy, Cambridge MA, Harvard University Press

SCHÖN, D. and REIN, M. (1994), Frame Reflection: Toward the Resolution of Intractable Policy Controversies, London, Basic Books

STEPHENS, M. (2007), 'Mortgage market deregulation and its consequences', Housing Studies, 22, 201-220

TAYLOR, M. and PHILLIPS, T. (2016), 'London mayor launches unprecedented inquiry into foreign property ownership', The Guardian, 30 September 2016

TUNSTALL, B. (2015), 'Relative housing space inequality in England and Wales, and its recent rapid resurgence', International Journal of Housing Policy, 15, 105-126

TURNER, G. (2008), The Credit Crunch: Housing Bubbles, Globalisation and the Worldwide Economic Crisis, London, Pluto Books

WAINWRIGHT, T. (2009), 'Laying the foundations for a crisis: Mapping the historico-geographical construction of Residential Mortgage Backed Securitization in the UK', in International Journal of Urban and Regional Research, 33, 372-388

WHITEHEAD, C.M.E. (1991), 'From Need to Affordability: An Analysis of UK Housing Objectives', Urban Studies, 28, 871-887

WHITEHEAD, C.M.E. (2016), Using projections of household numbers - tensions between planning and economics, Town and Country Planning, 85, 415-421

WILLIAMS, Z. (2016), 'Donald Trump has thrown caution to the wind. So must the left', The Guardian, (Accessed 20 June 2016 at http://www.theguardian.com/commentisfree /2016/mar/06/donald-trump-caution-to-wind-leftwingersstymied-pedantic-reserve) 